\title{
Relationship between Banks' Capital and Credit Risk-Taking through Syndicated Loan
}

\author{
Shu Ling Lin, Wei Peng Chen, Jun Lu \\ Department of Information and Finance Management, College of Management, National Taipei University of \\ Technology, Taiwan \\ Email: shuling@ntut.edu.tw, shulingntut@gmail.com,wpc@ntut.edu.tw, aborigine.lu@gmail.com
}

Received 27 November 2015; accepted 23 December 2015; published 29 December 2015

Copyright (C) 2015 by authors and Scientific Research Publishing Inc.

This work is licensed under the Creative Commons Attribution International License (CC BY).

http://creativecommons.org/licenses/by/4.0/

(c) (i) Open Access

\section{Abstract}

This paper aims to investigate whether banks exploit their information advantage over bank-dependent borrowers, analyzing the impact of capital level on banking credit risk-taking under syndication loans. By using a unique data composed of $\mathbf{4 8 2 8}$ syndicated loan of publicity banks facilities from the U.S. for the period 1987-2010, we propose theoretical issues of the impact and effectiveness of banks' credit risk-taking from the perspectives of borrowers' bank dependent. The results show that there is positive correlation between the ratios of bank's capital over its total assets and banks' credit risk-taking. It implies that banks with lower capital level charge higher lending spread for borrowers with fewer cash flows; hence the banks would bear a lower probability of default.

\section{Keywords}

Capital Regulation, Syndication Loans, Credit Risk-Taking, Nonperforming Loan (NPL), Probability of Default

\section{Introduction}

Since the subprime mortgage crisis began in 2007, bank with low capital led to significant cutbacks in lending caused by huge credit crunches. It is critically important for authorities to better understand the relation between bank capital levels and lending behavior, and seek to oversee the stability and its impact on the wider financial system. Existing studies on the effect of the banks' lending behavior have begun to draw more attention recently, but the consequences on banks' credit risk-taking have been relatively scarce.

Recently, several theories advocate that a banks' capital level should affect their lending behavior (Gadanecz, 
et al.; Kim, et al.) [1] [2]. Sharpe [3] and Rajan [4] propose successively the theories on banks' information monopoly; and predict that banks with low capital should charge higher lending rates to borrowers that are more bank-dependent. Hence, banks with low capital would obtain higher return and take lower risk. By contrast, Boot et al. [5] suggest the theory of sacrificing reputational capital and predict that banks with low capital are more likely to exploit borrowers in order to preserve financial capital. Subsequently, Diamond and Rajan [6] argue that banks with low capital much focus on obtaining cash flow quickly, thus they may charge more to borrowers with low cash flow; however, give large discounts to borrowers with high cash flow.

Through the perspective of supervision mechanism, the study tests the hypotheses linked to the predictions of Diamond and Rajan's [6] theory of bank capital and Sharpe [3] and Rajan's [4] theory of informational monopolies advantage on a sample of syndication loans to publicly-traded borrowers from 1987-2010, and examines the links among banks' capital, banks' lending behavior, and banks' credit risk-taking. Key to the above theories is the notion that the informational monopolies advantage of a bank and its borrowers' relative bargaining power are critical as economies with different supervision mechanism. Specifically, the sample of this study comes from a total of 4828 syndication loans banks in the U.S. over the 1987-2010 periods that capture the effect of the 2008 financial crisis, and the study assesses that if banks with low capital level are more sensitive to borrowers' loan-amounts than banks with high capital. That is, banks with low capital charge relatively more for borrowers with low cash flows; however, offer relatively great discounts for borrowers with high cash flows. In addition, this study performs the robustness test to the inclusion of loan- and bank- specific controlling variables, to perceive if the results are consistent with either theory.

This study proposes theoretical issues of the impact and effectiveness of banks' credit risk-taking from the perspectives of borrowers' bank dependent. The banking sectors during the financial crisis caused by credit crunch also notice the importance of supervisiory mechanisms. Overall, one important task of this study is to explore the transitions of supervisory mechanism to the loan practices in baking sectors. The study contributions to the prior literatures are summarized as follows.

The study provides new insights resulting from supervisory mechanism prevalent in the U.S., and a total of 4828 samples of publicity banks over the 1987-2010 period that capture the effect of the 2008 financial crisis. In addition, this study analyzes the relationship among banks' capital, borrowers' loan-amount, banks' credit risktaking, and examines that if banks with low capital level are more sensitive to borrowers' cash flow than banks with high capital.

The main contribution of this paper is using of syndicated loan data and hence addition of many loan-specific and bank-specific characteristics as determinants of banks' credit risk, which attempts to investigate whether banks exploit their information advantage over bank-dependent borrowers. That is, this study proposes models and derives testable hypotheses to test the theory of bank capital (Diamond and Rajan) [6] and theory of information monopoly rents from bank-dependent borrowers (Sharpe; Rajan) [3] [4]. The study further examines the robustness of the above evidence by adding controlling variables of loan- and bank-specific characteristics.

The remainder of the project organized as follows. Section 2 reviews the theoretical and empirical literatures on the relationship among banks' capital level, lending behavior and credit risk. Sections 3 and 4 propose the hypotheses, empirical specification and data used in this study. Finally, section 5 outlines the empirical results and implications.

\section{Literatures Review}

\subsection{From the Perspective of Banks' Capital Level}

Some empirical studies are related to the impacts of banks' capital level on it borrowers reimburse. In assessing the impact of a bank's capital level on borrowers' refinancing rate, Diamond and Rajan [6] model how banks' lending decisions varies with their capital level and borrowers' cash flows. Hubbard et al. [7] hypothesize that banks with low capital will charge higher rates for borrowers with high switching costs, and examined the pricing of bank loans to publicly-traded firms in U.S. during the period of 1987-1992. The findings support their hypothesis. As Hubbard et al. [7], Steffen and Wahrenburg [8] test the hypothesis of Hubbard et al. [7] on UK bank loans to both publicly- and privately-traded firms during 1996-2005. The findings show that banks with low capital charge higher rates to borrowers with higher switching costs; however, the effect is limited to economic downturns.

Alternatively, Santos and Winton [9] investigate the importance of banks' information advantage and found 
that, when banks are likely to have greater information monopoly rents from bank-dependent borrowers, who without access debt market will pay higher rates than borrowers with such access, and the difference increases during recessions. Subsequently, Schenone [10] finds that borrowers pay higher rates before their stock IPO than after, and argued that this effect is related to bank informational monopolies. In addition, Hale and Santos [11] find that borrowers pay lower rates after their bond IPO; reflects a reduction in bank information monopolies. Contrary to the above literatures, Santos and Winton [12] focus solely on how bargaining power varies across banks depending on their capital level. The findings show that banks' capital level has a significant impact on the lending rates that their borrowers pay, consistent with Diamond and Rajan [6].

\subsection{From the Perspective of Banks' Reputation and Lending Incentives}

From the perspective of bank reputation and lending incentives, Boot et al. [5] forecast that banks with low capital may forfeit reputational capital by reneging on implicit guarantees, which is the commitment to not utilize monopoly power over borrowers. In Sharpe [3] and Rajan [4] single-period setting, banks can remove monopoly rents from bank-dependent borrowers through an informational delay mechanism. Santos and Winton [9] point out that the Winner's Curse should be larger in recessions. Consistently, Santos and Winton [9] find that the loan spreads charged to borrowers that do not have access to public bond markets increase in recessions. However, they also find that banks' reputation concerns may offset their incentive to exploit their monopoly rents in a multiperiod setting. Combining with the theory of banks' monopoly rents extraction, proposed by Boot $e t$ al. [5] and Santos and Winton's [9] theory of informational monopolies advantage, it follows that banks with poorer capital level should be further likely to sacrifice their reputation in order to keep or enhance their capital. Hubbard, et al. [7] finds their empirical results consistent with the above proposition.

\subsection{The Correlation between Bank Capital and Lending Rates}

The correlation between bank capital and lending rates may be driven by some other variables that affect both independently. Santos and Winton [12] find that capital matters for all borrowers, once we control for business conditions. They argue that a borrower's cash flow is more important for loan pricing in recessions, when the case is most useful in warding off default; banks suffer higher credit losses in recessions. Steffen and Wahrenburg [8] use UK firms from 1995-2005 and find that banks with lesser Tier-1 capital charge higher rates to bankdependent firms in recessions, in particular when potential rents and incentives to preserve capital are likely to be higher.

Despite the large number of research efforts attempting to elucidate the determinants of loan spread and credit risk-taking, evidences still remain inconclusive.

\section{Methodology}

\subsection{Hypotheses and Model Specifications}

Based upon the above discuss of the variation in supervision environment, and the differences in protection necessary to examine the links among banks' capital, borrowers' bank-dependence, banks' credit risk-taking. This study presents the following general proposition.

In assessing the impact of a bank's capital level on borrowers' refinancing rate, Diamond and Rajan [6] model how banks' lending decisions varies with their capital level and borrowers' cash flows. The perception is that a bank with low capital level is desperate to get cash to hold up its liquidity position vis-à-vis depositors. If the borrower's cash flow (proxy by borrower's loan-amount) is also rather weak, the bank has a plausible threat to liquidate the borrower to get cash; this makes the borrower willing to pay more to avoid liquidation. Hence, the bank would obtain higher return and lower default risk, and vice versa. Overall, compared to a bank that has adequate capital ratio, a bank that has low capital may extract more lending rates from borrowers whose cash situation is relatively weak to get higher return and take lower credit risk-taking, and vice versa.

Based upon the above discuss, this study proposes models and derives testable hypotheses, attempted to investigate whether banks exploit their information advantage over bank-dependent borrowers to test the theory of bank capital (Diamond and Rajan) [6] and theory of information monopoly rents from bank-dependent borrowers (Sharpe; Rajan) [3] [4]. Specifically, this study presents the following general proposition to examine the links between banks' capital, borrowers' bank-dependence, loan spreads that banks charge their borrowers, 
banks' credit risk-taking through syndication loans.

$H_{1}$ : Banks with lower capital level charge higher lending spread for borrowers with fewer cash flows; hence, banks with low capital would obtain higher return and bear a lower probability of default. In other words, there is a positive relationship between banks' capital level and the banks' credit risk-taking through through its syndicated lending activity.

$$
\begin{aligned}
\text { CREDITRISK }_{l, b, t}= & c+\alpha \times \text { CAPITAL }_{b, t-1}+\beta \times \text { LOANAMOUNT }_{f, t} \\
& +\chi \times\left(\text { CAPITAL }_{b, t-1} \times \text { LOANAMOUNT }_{f, t}\right)+v_{f, t}
\end{aligned}
$$

where CREDITRISK $_{l, b, t}$ is the nonperforming loan (NPL) ratio (Impaired Loans/Gross Loans - \%) loan $l$ from bank $b$ at issue date $t$. CAPITAL $L_{b, t-1}$ is the ratio of bank $b$ 's equity capital to total assets at date of $t-1$. $\operatorname{LOANAMOUNT}_{f, t}$ is a measure of firm $f$ 's syndication loan amounts from bank. $v_{f, t}$ is the error term.

To test the robustness and determine whether other controlled variables might impact of bank capital on risktaking, this study considers additional controlling variables for lending bank and loan and bank-specific characteristics, and proposes the following hypotheses:

$\mathrm{H}_{2}$ : Controlling for the state of the loan-specific characteristics, banks with lower capital level charge higher lending spread for borrowers with fewer cash flows; hence, banks with low capital would obtain higher return and bear a lower probability of default. In other words, there is a positive relationship between banks' capital level and the banks' credit risk-takingthrough its syndicated lending activity.

$$
\begin{aligned}
\text { CREDITRISK }_{l, b, t}= & c+\alpha \times \text { CAPITAL }_{b, t-1}+\beta \times \operatorname{LOANAMOUNT}_{f, t} \\
& +\chi \times\left(\text { CAPITAL }_{b, t-1} \times \operatorname{LOANAMOUNT}_{f, t}\right) \\
& +\sum_{i=1}^{I} \delta_{i} \times X_{i . l . t}+\varepsilon_{f, t}
\end{aligned}
$$

$\mathrm{H}_{3}$ : Controlling for the state of the bank-specific characteristics, banks with lower capital level charge higher lending spread for borrowers with fewer cash flows; hence, banks with low capital would obtain higher return and bear a lower probability of default. In other words, there is a positive relationship between banks' capital level and the banks' credit risk-takingthrough its syndicated lending activity.

$$
\begin{aligned}
\text { CREDITRISK }_{l, b, t}= & c+\alpha \times \text { CAPITAL }_{b, t-1}+\beta \times \operatorname{LOANAMOUNT}_{f, t} \\
& +\chi \times\left(\text { CAPITAL }_{b, t-1} \times \operatorname{LOANAMOUNT}_{f, t}\right) \\
& +\sum_{k=1}^{K} \varphi_{i, t} \times Z_{k, b, t}+\xi_{f, t}
\end{aligned}
$$

$\mathrm{H}_{4}$ : Controlling for the state of the bank- and loan-specific characteristics, banks with lower capital level charge higher lending spread for borrowers with fewer cash flows; hence, banks with low capital would obtain higher return and bear a lower probability of default. In other words, there is a positive relationship between banks' capital level and the banks' credit risk-takingthrough its syndicated lending activity.

$$
\begin{aligned}
\text { CREDITRISK }_{l, b, t}= & c+\alpha \times \text { CAPITAL }_{b, t-1}+\beta \times \operatorname{LOANAMOUNT}_{f, t} \\
& +\chi \times\left(\text { CAPITAL }_{b, t-1} \times \operatorname{LOANAMOUNT}_{f, t}\right) \\
& +\sum_{i=1}^{I} \delta_{i} \times X_{i . l . t}+\sum_{k=1}^{K} \varphi_{i, t} \times Z_{k, b, t}+\psi_{f, t}
\end{aligned}
$$

where $X_{i, l, t}$ represents the loan-specific variables, proposed by Berger and Udell [13] as well as Santos and Winton [12]. $Z_{i, l . t}$ represents the bank-specific controlling variables, proposed by Santos and Winton [12] that may affect banks' willingness or capability to supply funds. $\varepsilon_{f, t}, \xi_{f, t}, \psi_{f, t}$ are the error term.

\subsection{Variables and Data}

\subsubsection{Variables of Loan-Specific Characteristics}

- Loan Restrictions, which include three dummy variables equal to one if the loan is senior (SENIOR), is secured (SECURED), or has a guarantor (GUARANTOR); otherwise, equal to zero. Berger and Udell [13] 
suggest that any of these features should make the loan safer, decreasing the loan spreads, but it is well known that lenders more likely to require these features if they think the firm is riskier, so the relationship may be reversed or ambiguous.

- Loans maturity (LMATURITY), measured by the time to maturity in years. Santos and Winton [12] propose that loans with longer maturities may face greater credit risk, but they are more likely to be granted to borrowers that are thought to be more creditworthy. Thus again, the effect on loan spreads is ambiguous.

- Loans amount (LAMOUNT), calculated by the nature log of loan amount. It expects that larger loans amount may represent more credit risk, raising the loan rate, but they may also allow economies of scale in processing and monitoring the loan. Accordingly, the sing of this variables' effect on loan spreads is ambiguous.

- Loans purposes, which include two dummy variables equal to one if the loan taken out for working capital purposes (WORKCAPITAL) and for corporate purposes (CORPORPOSES); otherwise, equal to zero.

- Type of loan (TYPELOAN), which is a dummy variable equal to one of -whether it is a term loan; otherwise, equal to zero.

- Syndicate arrangers (LEADBANKERS), measured by the number of lead arrangers in the syndicate. Santos and Winton [12] suggest that multiple lead arrangers may lead to free rider problems in monitoring the borrower, thus, this study expects that this would lead to higher loan spreads.

- Relationship of borrowers with lead arranger (RELATIONSHIP), which is a dummy variable equal to one if the firm borrowed from the same lead arranger in the three years prior to the current loan. Santos and Winton [12] advise that this implies that a relationship may give the borrower the benefit of a lower loan spread, but it is also possible that it indicates greater information monopoly, leading to higher loan spreads. Bharath, et al. [14] find that the impact of a relationship on loan spreads is negative. On the other hand, Santos and Winton [12] find that this effect is reversed in recessions, while information monopolies are likely to be stronger and maintaining relationships is likely to be less attractive to lenders.

\subsubsection{Variables of Bank-Specific Characteristics}

- Bank's total assets (LASSETS), calculated by the nature log of the bank’s total assets to control for banks’ size. Santos and Winton [12] suggest that larger banks may be better-diversified or have better entrance to funding markets, leading to a lower cost of funds. Therefore, this study predicts a lower loan spreads relative to LIBOR.

- Subordinated debt ( $S U B D E B T)$, which is calculated by a bank's subordinated debt as a fraction of assets, which is proxy as bank equity capital, or an indicator of bank access to public debt markets. In each case, this study expects that the impact on loan spreads should be negative.

- Bank's liquidity (LIQUIDITY), measured by the bank's cash and marketable securities as a fraction of total assets, which is proxy for the bank's cost of funds. This study predicts that banks with more liquid assets should find it easier to fund loans on the margin, thus leading to lower loan spreads.

\subsubsection{Samples and Data Source}

This study constructs a data set containing 17,030 syndication loans from the U.S. banking for the period 19872010. The data after 2011 will not affect the results of the study. The data used in this study came from several data sources, including as follows:

- The Loan Pricing Corporation's Dealscan database (LPC), which includes business loans to identify the corporations that borrowed from banks and when they did so. Furthermore, the Dealscan database also provides information on: individual loans, including loan's spread over Libor, maturity, seniority status, purpose and type. On the side of borrowers' information, including its sector of activity, and its legal status (private or public firm), and the lending syndicate, as well as the identity and role of the banks in the loan syndicate.

- Compustat, which includes corporations' balance sheet. Given that Compustat is dominated by publicly-held firms, this study has to exclude loans to private-held firms from the sample.

- BankScope database, which provides data of balance sheet and income statement of publicly banks in thousands of US dollars.

\subsection{Statistics Method}

The estimation formed by Equations (1)-(4) is carried out by ordinay least square (OLS) estimation to obtain 
consistent parameter estimates, as the use of pairwise regression to eliminate or reduce estimation bias. In addition, to keep away from collinearity problem on controlled variables, the study conducts pearson correlation analysis to examine the presence of collinearity and excludes variables with collinearity. Furthermore, in order to provide a robust empirical result in this study, generalized method of moment (GMM; Gambacorta and Mistrulli) [15] makes use of the orthogonality conditions to allow for efficient estimation in the presence of heteroskedasticity of unknown form. Furthermore, the GMM approach places no restrictions on either the conditional or unconditional variance matrix of the disturbance term. Under the GMM framework, we can obtain an asymptotically efficient estimator without making any additional assumptions, and this will clearly enable us to obtain the most robust results.

\section{Empirical Results}

This study constructs a data set containing 17,030 syndication loans from the U.S. banking for the period 19872010. To get a relatively homogenous sample of banks, this study bounds the variables at $0.01 \%$. In addition, this study also drops the missing values for corporations that did not report their total capital ratio. For at least two consecutive years is deleted from the data set for these firms. Thus, the multiple regression estimation carried out by 4828 valid observations.

\subsection{Descriptive Statistics}

Table 1 shows the descriptive statistics of the variables in this study. The mean value of bank's capital over its total assets is $9.701 \%$, higher than the norms of BIS regulation. On the side of credit risk, the mean value of NPL ratio Impaired Loans over Gross Loans in the U.S. during the periods of 1987-2010 is $1.897 \%$. On the side of syndication loan, the mean value of syndication loan is about966 million dollars. The syndication loan restric-

Table 1. Descriptive statistics.

\begin{tabular}{|c|c|c|c|c|c|}
\hline & $\mathrm{N}$ & Min & Max & Mean & Std. Dev. \\
\hline \multicolumn{6}{|c|}{ Panel A: Variables of Loan-specific characteristics } \\
\hline NPL ratio Impaired Loans/Gross Loans - \% & 4828 & 0.000 & 83.814 & 1.897 & 4.589 \\
\hline Loan amount (LAMOUNT) & 17,030 & $1.50 \mathrm{E}+05$ & $2.40 \mathrm{E}+10$ & $9.66 \mathrm{E}+08$ & $1.90 \mathrm{E}+09$ \\
\hline Loan Restrictions-SENIOR & 17,030 & 0.000 & 1.000 & 0.997 & 0.056 \\
\hline Loan Restrictions-SECURED & 17,030 & 0.000 & 1.000 & 0.594 & 0.491 \\
\hline Loan Restrictions-GUARANTOR & 17,030 & 0.000 & 1.000 & 0.118 & 0.323 \\
\hline Loan maturity (LMATURITY) & 17,030 & 0.083 & 60.000 & 4.626 & 2.263 \\
\hline Loan purposes (WORKCAPITAL) & 17,030 & 0.000 & 1.000 & 0.076 & 0.264 \\
\hline Loan purposes (CORPORPOSES) & 17,030 & 0.000 & 1.000 & 0.490 & 0.500 \\
\hline Type of loan (TYPELOAN) & 17,030 & 0.000 & 1.000 & 0.770 & 0.421 \\
\hline LEADBANKERS & 17,030 & 0.000 & 1.000 & 0.260 & 0.439 \\
\hline RELATIONSHIP & 17,029 & 0.000 & 1.000 & 0.743 & 0.437 \\
\hline \multicolumn{6}{|c|}{ Panel B: Variables of Bank-Specific Characteristics } \\
\hline Bank's capital (t-1) Equity/Total Assets - \% & 6348 & 0.058 & 99.660 & 9.701 & 11.847 \\
\hline LASSETS & 6404 & $2.27 \mathrm{E}+00$ & $7.60 \mathrm{E}+08$ & $1.03 \mathrm{E}+07$ & $5.17 \mathrm{E}+07$ \\
\hline SUBDEBT & 5316 & 0.000 & 0.216 & 0.018 & 0.021 \\
\hline LIQUIDITY & 5958 & 0.000 & 0.995 & 0.030 & 0.044 \\
\hline
\end{tabular}


tions are non-diversification, senior, secured, and have some guarantor, it implies that the banks are risk-sensitive and need more protection in order to reduce its credit risk. The mean maturity of syndication loan is 4.626 years. The purposes of syndication loan are most repay corporate existing debt and for its working capital. The type of syndication loan is a line of credit or a term loan, but not a renewal of an existing loan. The bank is almost as syndicate arrangers and the borrowers have relationship with lead arrangers.

\subsection{Correlation Analysis}

Table 2 provides the correlation coefficients between the loan-specific variables and the bank-specific variables, with a strong positive correlation being discernible between the NPL ratio and the bank capital ratio. A significantly positive correlation is also found between the loan amount and the NPL ratio; however, the correlation between the bank capital ratio and the loan amount is negative. Furthermore, these relationships suggest that there is a significant relationship between banks' capital level and the banks' credit risk-taking through its syndicated lending activity. Overall, the result of Table 2 presents the lower correlation coefficients within these variables, implying that there is no multicollinearity problem in the regression analysis. This result is also consistent with the lower VIFs in the regression models.

\subsection{The Impact of Capital Level on Banking Lending Credit Risk: Controlling for the State of the Loan-Specific Characteristics}

On the impact of capital level on banking lending credit risk (NPL \%) in the U.S during 1987-2010, Table 3 shows that there is positive correlation between the ratios of bank's capital over its total assets and NPL, the coefficient is 1.596 and signification at $1 \%$. The result shows that compared to adequately capitalized banks,

\section{Table 2. Pearson Correlation Matrix.}

\begin{tabular}{|c|c|c|c|c|c|c|c|c|c|c|c|c|c|c|c|}
\hline & Y & $P$ & $\mathrm{~L}$ & $\mathrm{X} 1$ & $\mathrm{X} 2$ & X3 & $\mathrm{X} 4$ & X5 & X6 & X7 & $\mathrm{X} 8$ & X9 & $\mathrm{Z} 1$ & $\mathrm{Z} 2$ & $\mathrm{Z3}$ \\
\hline Y & 1 & & & & & & & & & & & & & & \\
\hline $\mathrm{P}$ & $0.062^{* * *}$ & 1 & & & & & & & & & & & & & \\
\hline $\mathrm{L}$ & $0.125^{* * *}$ & $-0.154^{* * *}$ & 1 & & & & & & & & & & & & \\
\hline $\mathrm{X} 1$ & 0.007 & 0.021 & $0.048^{* * *}$ & 1 & & & & & & & & & & & \\
\hline $\mathrm{X} 2$ & $-0.104^{* * *}$ & $0.087^{* * *}$ & $-0.265^{* * *}$ & $0.041^{* * *}$ & 1 & & & & & & & & & & \\
\hline X3 & -0.001 & 0.001 & $0.045^{* * *}$ & 0.025 & -0.008 & 1 & & & & & & & & & \\
\hline $\mathrm{X} 4$ & $-0.038^{* *}$ & $0.098^{* * *}$ & $-0.163^{* * *}$ & $-0.086^{* * *}$ & $0.338^{* * *}$ & $-0.068^{* * *}$ & 1 & & & & & & & & \\
\hline X5 & 0.000 & $-0.046^{* * *}$ & -0.005 & 0.009 & -0.015 & $0.063^{* * *}$ & $-0.027^{*}$ & 1 & & & & & & & \\
\hline $\mathrm{X} 6$ & -0.021 & $0.106^{* * *}$ & $0.029^{*}$ & $0.065^{* * *}$ & $0.187^{* * *}$ & 0.022 & $0.108^{* * *}$ & $-0.096^{* * *}$ & 1 & & & & & & \\
\hline X7 - & $-0.043^{* * *}$ & $* 0.022$ & $-0.126^{* * *}$ & $0.053^{* * *}$ & $0.156^{* * *}$ & 0.008 & $0.346^{* * *}$ & -0.024 & $0.149^{* * *}$ & 1 & & & & & \\
\hline $\mathrm{X} 8$ & $0.050^{* * *}$ & $-0.097^{* * *}$ & $-0.028^{*}$ & 0.004 & -0.014 & $-0.032^{* *}$ & -0.025 & -0.012 & $-0.121^{* * *}$ & -0.016 & 1 & & & & \\
\hline X9 & $-0.037^{* *}$ & 0.011 & $-0.195^{* * *}$ & -0.017 & $0.211^{* * *}$ & 0.007 & $0.168^{* * *}$ & $-0.106^{* * *}$ & * 0.025 & $0.106^{* * *}$ & $0.056^{* * *}$ & 1 & & & \\
\hline $\mathrm{Z} 1$ & -0.021 & $-0.102^{* * *}$ & 0.014 & -0.016 & $-0.055^{* * *}$ & $0.053^{* * *}$ & -0.004 & -0.012 & -0.012 & 0.017 & -0.013 & -0.008 & 1 & & \\
\hline $\mathrm{Z2}$ & $-0.031^{* *}$ & $0.083^{* * *}$ & 0.002 & -0.018 & $-0.064^{* * *}$ & $-0.041^{* * *}$ & $-0.047^{* * *}$ & ${ }^{*}-0.033^{* *}$ & -0.015 & 0.008 & 0.005 & -0.008 & -0.003 & 1 & \\
\hline Z3 & $0.281^{* * *}$ & $-0.157^{* * *}$ & $0.096^{* * *}$ & -0.010 & $-0.038^{* *}$ & 0.025 & 0.000 & $0.035^{* *}$ & $-0.089^{* * *}$ & $-0.045^{* * *}$ & $0.252^{* * *}$ & $-0.031^{* *}$ & 0.014 & $-0.102^{* * *}$ & ${ }^{*} 1$ \\
\hline
\end{tabular}

Note: Y is the NPL ratio (Impaired Loan/Gross Loan); P is the ratio of bank's equity capital to total assets (Bank's capital Equity/Total Assets); L is the syndication loan amount (LAMOUNT); X1 is a dummy variable that whether it is senior (SENIOR); X2 is a dummy variable that whether it is secured (SECURED); X3 is a dummy variable that whether it has a guarantor (GUARANTOR); X4 is the loan maturity in years (LMATURITY); X5 is a dummy variable that whether the loan taken out for working capital purposes (WORKCAPITAL); X6 is a dummy variable that whether the loan taken out for corporate purposes (CORPORPOSES); X7 is a dummy variable that whether it is a term loan (TYPELOAN); X8 is the number of lead arrangers in the syndicate (LEADBANKERS); X9 is a dummy variable that whether the firm borrowed from the same lead arranger in the three prior to the current loan (RELATIONSHIP). ${ }^{* * *}$ indicates the significance of the traditional t-test at the $1 \%$ level; ${ }^{* *}$ indicates significance at the $5 \%$ level; and ${ }^{*}$ indicates significance at the $10 \%$ level. 
Table 3. Impact of capital level on banking lending credit risk (NPL\%) in the U.S. syndicated loan for the period 1987-2010.

$$
\begin{aligned}
\text { CREDITRISK }_{l, b, t}= & c+\alpha \times \text { CAPITAL }_{b, t-1}+\beta \times \text { LOANAMOUNT }_{f, t} \\
& +\chi \times\left(\text { CAPITAL }_{b, t-1} \times \text { LOANAMOUNT }_{f, t}\right)+v_{f, t}
\end{aligned}
$$

\begin{tabular}{|c|c|c|c|}
\hline \multirow{2}{*}{$\begin{array}{c}\text { Dependent variable: } \\
\text { NPL Impaired Loans/Gross Loans (\%) }\end{array}$} & \multirow{2}{*}{ Coefficient } & OLS & GMM \\
\hline & & t-statistic & t-statistic \\
\hline (Constant) & -16.643 & $-9.425^{* * *}$ & $-3.493^{* * *}$ \\
\hline Bank's capital $(t-1)$ Equity/Total Assets - \% & 1.596 & $9.097^{* * *}$ & $2.748^{* * *}$ \\
\hline Loan amount (LAMOUNT) & 0.795 & $9.049^{* * *}$ & $3.415^{* * *}$ \\
\hline Capital $(t-1) *$ Loan-Amount & -0.064 & $-7.349^{* * *}$ & $-2.247^{* *}$ \\
\hline Adj- $R^{2}$ & & 0.132 & \\
\hline Observation & & 4597 & \\
\hline
\end{tabular}

Note: ${ }^{* * *}$ indicates the significance of the traditional t-test at the $1 \%$ level; ${ }^{* *}$ indicates significance at the $5 \%$ level; and ${ }^{*}$ indicates significance at the $10 \%$ level.

banks with lower capital level charge higher lending spread for borrowers with fewer cash flows, hence obtain higher return of assets, but lower lending credit risk-taking. In addition, the interaction effects of capital and loan-amount on banks' lending credit risk is positive, the coefficient is -0.064 and signification at $5 \%$. The adjusted $\mathrm{R}^{2}$ is $13.2 \%$. In addition, in terms of statistical significance, the results of OLS and GMM reached the consistency. The results meet the expectation of hypothesis 1 and theory of information monopoly rents from bank-dependent borrowers (Sharpe; Rajan) [3] [4].

On the impact of capital level on banking credit risk-taking (NPL \%) controlling for the state of the loanspecific characteristics in the U.S syndicated loan for the period 1987-2010, Table 4 shows that there is positive correlation between the ratios of bank's capital over its total assets and NPL (\%), the coefficient is 1.611 and signification at $1 \%$. The result shows that compared to adequately capitalized banks, banks with lower capital level charge higher lending spread for borrowers with fewer cash flows, hence the banks would bear a lower probability of default and credit risk-taking, but higher credit risk for borrowers with strong cash flows. In addition, there is positive correlation between the ratios of borrowers' loan-amount and NPL (\%), the coefficient is 0.783 and signification at $1 \%$. The adjusted $\mathrm{R}^{2}$ is $14.9 \%$. In addition, in terms of statistical significance, the results of OLS and GMM reached the consistency. The results meet the expectation of hypothesis 3 and Table 3. That is, controlling for the state of the loan-specific characteristics, there is a positive relationship between banks' capital level and the banks' credit risk-taking. The results are coincident with findings of the Boot et al. [5] and Santos and Winton's [9] theory of informational monopolies advantage.

The coefficients of the control variables, i.e., Loan purposes (WORKCAPITAL), LEADBANKERS, and RELATIONSHIP, are all significantly positive, indicating that the banking lending credit risk would be affected by the loan for working capital purpose, the number of lead arrangers in the syndicate, and the relationship between borrowers and lead arranger. In addition, the coefficients of control variables, i.e., Loan purposes (CORPORPOSE) and Loan restrictions (SECURED), are found to be negatively related to the banking lending credit risk, a finding which the loan purpose for corporate purpose and the loan with secured restriction act as effective roles on the reduction of the banking lending credit risk.

\subsection{The Impact of Capital Level on Banking Lending Credit Risk: Controlling for the State of the Bank-Specific Characteristics}

On the impact of capital level on banking credit risk-taking (NPL\%) controlling for the state of the bank-specific characteristics in the U.S syndicated loan for the period 1987-2010, Table 5 shows that there is positive correlation between the ratios of bank's capital over its total assets and NPL (\%), the coefficient is 0.648 and signification at $1 \%$. The result shows that compared to adequately capitalized banks, banks with lower capital level charge higher lending spread for borrowers with fewer cash flows, hence the banks would bear a lower probability of default and credit risk-taking, but higher credit risk for borrowers with strong cash flows. In addition, there 
Table 4. Impact of capital level on banking lending credit risk (NPL\%) with considering the loan-specific characteristicsin the U.S. syndicated loan for the period 1987-2010.

$$
\begin{aligned}
\text { CREDITRISK }_{l, b, t}= & c+\alpha \times \text { CAPITAL }_{b, t-1}+\beta \times \text { LOANAMOUNT }_{f, t} \\
& +\chi \times\left(\text { CAPITAL }_{b, t-1} \times \operatorname{LOANAMOUNT~}_{f, t}\right) \\
& +\sum_{i=1}^{I} \delta_{i} \times X_{i . l . t}+\varepsilon_{f, t}
\end{aligned}
$$

\begin{tabular}{|c|c|c|c|}
\hline \multirow{2}{*}{$\begin{array}{c}\text { Dependent variable: } \\
\text { NPL Impaired Loans/Gross Loans (\%) }\end{array}$} & \multirow{2}{*}{ Coefficient } & OLS & \multirow{2}{*}{$\begin{array}{c}\text { GMM } \\
\text { t-statistic }\end{array}$} \\
\hline & & t-statistic & \\
\hline (Constant) & -15.988 & $-7.391^{* * *}$ & $-3.429^{* * *}$ \\
\hline Bank's capital $(t-1)$ Equity/Total Assets - \% & 1.611 & $9.235^{* * *}$ & $2.812^{* * *}$ \\
\hline Loan amount (LAMOUNT) & 0.783 & $8.788^{* * *}$ & $3.350^{* * *}$ \\
\hline Capital $(t-1) *$ Loan-Amount & -0.064 & $-7.433^{* * *}$ & $-2.296^{* *}$ \\
\hline Loan Restrictions-SENIOR & -0.093 & -0.074 & -0.160 \\
\hline Loan Restrictions-SECURED & -0.378 & $-2.587^{* * *}$ & $-2.242^{* *}$ \\
\hline Loan Restrictions-GUARANTOR & -0.091 & -0.539 & -0.598 \\
\hline Loan maturity (LMATURITY) & -0.034 & -0.930 & -0.615 \\
\hline Loan purposes (WORKCAPITAL) & 1.699 & $4.448^{* * *}$ & $2.157^{* *}$ \\
\hline Loan purposes (CORPORPOSES) & -0.597 & $-4.442^{* * *}$ & $-3.859^{* * *}$ \\
\hline Type of loan (TYPELOAN) & -0.216 & -1.234 & -1.042 \\
\hline LEADBANKERS & 0.710 & $4.989^{* * *}$ & $4.009^{* * *}$ \\
\hline RELATIONSHIP & 0.363 & $2.223^{* *}$ & $2.315^{* *}$ \\
\hline Adj- $R^{2}$ & & 0.149 & \\
\hline Observation & & 4597 & \\
\hline
\end{tabular}

Note: ${ }^{* * *}$ indicates the significance of the traditional t-test at the $1 \%$ level; ${ }^{* *}$ indicates significance at the $5 \%$ level; and ${ }^{*}$ indicates significance at the $10 \%$ level.

Table 5. Impact of capital level on banking lending credit risk with considering the bank-specific characteristics in the U.S syndicated loanfor the period 1987-2010.

\begin{tabular}{|c|c|c|c|}
\hline \multirow{2}{*}{$\begin{array}{l}\text { Dependent variable: } \\
\text { NPL Impaired Loans/Gross Loans (\%) }\end{array}$} & \multirow{2}{*}{ Coefficient } & OLS & GMM \\
\hline & & t-statistic & t-statistic \\
\hline (Constant) & -6.016 & $-7.227^{* * *}$ & $-4.616^{* * *}$ \\
\hline Bank's capital $(t-1)$ Equity/Total Assets - \% & 0.648 & $6.735^{* * *}$ & $4.495^{* * *}$ \\
\hline Loan amount (LAMOUNT) & 0.429 & $10.307^{* * *}$ & $6.401^{* * *}$ \\
\hline Capital $(t-1) *$ Loan-Amount & -0.039 & $-7.923^{* * *}$ & $-5.123^{* * *}$ \\
\hline LASSETS & -0.002 & $-3.293^{* * *}$ & $-4.603^{* * *}$ \\
\hline SUBDEBT & -1.502 & -0.674 & -0.480 \\
\hline LIQUIDITY & -5.014 & $-4.020^{* * *}$ & $-3.663^{* * *}$ \\
\hline Adj- $R^{2}$ & & 0.092 & \\
\hline Observation & & 3672 & \\
\hline
\end{tabular}

$$
\begin{aligned}
\text { CREDITRISK }_{l, b, t}= & c+\alpha \times \text { CAPITAL }_{b, t-1}+\beta \times \operatorname{LOANAMOUNT}_{f, t} \\
& +\chi \times\left(\text { CAPITAL }_{b, t-1} \times \operatorname{LOANAMOUNT}_{f, t}\right) \\
& +\sum_{k=1}^{K} \varphi_{i, t} \times Z_{k, b, t}+\xi_{f, t}
\end{aligned}
$$

Note: ${ }^{* * *}$ indicates the significance of the traditional t-test at the $1 \%$ level; ${ }^{* *}$ indicates significance at the $5 \%$ level; and ${ }^{*}$ indicates significance at the $10 \%$ level. 
is positive correlation between the ratios of borrowers' loan-amount and NPL (\%), the coefficient is 0.429 and signification at $1 \%$. The adjusted $\mathrm{R}^{2}$ is $9.2 \%$. In addition, in terms of statistical significance, the results of OLS and GMM reached the consistency. The results meet the expectation of hypothesis 3 and Table 3 and Table 4. That is, controlling for the state of the bank-specific characteristics, there is a positive relationship between banks' capital level and the banks' credit risk-taking. The results are coincident with findings of the Boot et al. [5] and Santos and Winton's [9] theory of informational monopolies advantage.

The coefficients of control variables, i.e., LASSETS and LIQUIDITY, are found to be negatively related to the banking lending credit risk, indicating that the bank size and liquidity have effects on lowering the banking lending credit risk.

On the impact of capital level on banking credit risk-taking (NPL\%) controlling for the state of the loanspecific and bank-specific characteristics in the U.S syndicated loan for the period 1987-2010, Table 6 shows that there is positive correlation between the ratios of bank's capital over its total assets and NPL (\%), the coefficient is 0.599 and signification at $1 \%$. The result shows that compared to adequately capitalized banks, banks with lower capital level charge higher lending spread for borrowers with fewer cash flows, hence the banks would bear a lower probability of default and credit risk-taking, but higher credit risk for borrowers with strong

Table 6. Impact of capital level on banking lending credit risk with considering the loan-specific and bank-specific characteristics in the U.S syndicated loan for the period 1987-2010.

$$
\begin{aligned}
\text { CREDITRISK }_{l, b, t}= & c+\alpha \times \text { CAPITAL }_{b, t-1}+\beta \times \text { LOANAMOUNT }_{f, t} \\
& +\chi \times\left(\text { CAPITAL }_{b, t-1} \times \operatorname{LOANAMOUNT}_{f, t}\right) \\
& +\sum_{i=1}^{I} \delta_{i} \times X_{i . l . t}+\sum_{k=1}^{K} \varphi_{i, t} \times Z_{k, b, t}+\psi_{f, t}
\end{aligned}
$$

\begin{tabular}{|c|c|c|c|}
\hline \multirow{2}{*}{$\begin{array}{l}\text { Dependent variable: } \\
\text { NPL Impaired Loans/Gross Loans (\%) }\end{array}$} & \multirow{2}{*}{ Coefficient } & \multirow{2}{*}{$\begin{array}{c}\text { OLS } \\
\text { t-statistic }\end{array}$} & \multirow{2}{*}{$\begin{array}{c}\text { GMM } \\
\text { t-statistic }\end{array}$} \\
\hline & & & \\
\hline (Constant) & -5.131 & $-5.350^{* * *}$ & $-3.542^{* * *}$ \\
\hline Bank’s capital $(t-1)$ Equity/Total Assets \% & 0.599 & $6.179^{* * *}$ & $3.937^{* * *}$ \\
\hline Loan amount (LAMOUNT) & 0.393 & $9.133^{* * *}$ & $5.322^{* * *}$ \\
\hline Capital $(t-1) *$ Loan-Amount & -0.036 & $-7.334^{* * *}$ & $-4.512^{* * *}$ \\
\hline Loan Restrictions-SENIOR & 0.000 & -0.001 & -0.001 \\
\hline Loan Restrictions-SECURED & -0.128 & $-2.234^{* *}$ & $-2.003^{* *}$ \\
\hline Loan Restrictions-GUARANTOR & -0.022 & -0.336 & -0.358 \\
\hline Loan maturity (LMATURITY) & -0.045 & $-3.194^{* * *}$ & $-2.948^{* * *}$ \\
\hline Loan purposes (WORKCAPITAL) & -0.014 & -0.094 & -0.095 \\
\hline Loan purposes (CORPORPOSES) & 0.132 & $2.496^{* *}$ & $2.556^{* *}$ \\
\hline Type of loan (TYPELOAN) & -0.064 & -0.944 & -0.920 \\
\hline LEADBANKERS & 0.077 & 1.336 & 1.370 \\
\hline RELATIONSHIP & 0.123 & $1.922^{*}$ & $1.935^{*}$ \\
\hline LASSETS & -0.002 & $-3.322^{* * *}$ & $-4.703^{* * * *}$ \\
\hline SUBDEBT & -2.273 & -1.017 & -0.718 \\
\hline LIQUIDITY & -5.226 & $-4.059^{* * * *}$ & $-3.839^{* * * *}$ \\
\hline Adj- $R^{2}$ & & 0.097 & \\
\hline Observation & & 3672 & \\
\hline
\end{tabular}

Note: ${ }^{* * *}$ indicates the significance of the traditional t-test at the $1 \%$ level; ${ }^{* *}$ indicates significance at the $5 \%$ level; and ${ }^{*}$ indicates significance at the $10 \%$ level. 
cash flows. In addition, there is positive correlation between the ratios of borrowers' loan-amount and NPL (\%), the coefficient is 0.393 and signification at $1 \%$. The adjusted $\mathrm{R}^{2}$ is $9.7 \%$. In addition, in terms of statistical significance, the results of OLS and GMM reached the consistency. The results meet the expectation of hypothesis 4 and Tables 3-5. That is, controlling for the state of the loan-specific and bank-specific characteristics, there is a positive relationship between banks' capital level and the banks' credit risk-taking. The results are coincident with findings of the Boot et al. [5] and Santos and Winton's [9] theory of informational monopolies advantage.

Our empirical results provide overall support for our primary hypothesis that banks with lower capital level charge higher lending spread for borrowers with fewer cash flows; hence, banks with low capital would obtain higher return and bear a lower probability of default. These findings strengthen the influence of the bank capital on the banking lending credit risk.

\section{Concluding Remarks}

This study proposes theoretical issues of the impact and effectiveness of banks' credit risk-taking from the perspectives of borrowers' bank dependent. The banking sectors during the financial crisis caused by credit crunch also notice the importance of supervisiory mechanisms. Overall, one important task of this study is to explore the transitions of supervisory mechanism to the loan practices in baking sectors. The study contributions to the prior literatures are summarized as follows.

The study provides new insights resulting from supervisory mechanism prevalent in the U.S., and a total of 4828 samples of publicity banks over the 1987-2010 period that capture the effect of the 2008 financial crisis. In addition, the study analyzes the impact of capital regulation on banking credit risk-taking through its syndication lending activity. The objective of this study is attempted to investigate whether banks exploit their information advantage over bank-dependent borrowers, and propose models and derive testable hypotheses to test the theory of bank capital (Diamond and Rajan) [6] and theory of information monopoly rents from bank-dependent borrowers (Sharpe; Rajan) [3] [4]. Finally, the study further examines the robustness of the above evidences by adding controlling variables of loan- and bank-specific characteristics.

On the impact of capital level on banking credit risk-taking, the results show that there is positive correlation between the ratios of bank's capital over its total assets and credit risk-taking. It implies that compared to adequately capitalized banks, banks with lower capital level charge higher lending spread for borrowers with fewer cash flows; hence the banks would bear a lower probability of default and credit risk, but higher credit risktaking for borrowers with strong cash flows. When controlling for the state of the bank- and loan-specific characteristics, the effects are the same and meet the expectation of hypothesis 1 - 4. In terms of statistical significance, the results of OLS and GMM reached the consistency. The results imply the importance of banks' information monopoly rents from bank-dependent borrowers. The implications would be provided with policy implication to supervisory authority.

\section{Acknowledgements}

This work was financially supported by the National Science Council in Taiwan under NSC99-2410-H-027-005.

\section{References}

[1] Gadanecz, B., Tsatsaronis, K. and Altunba, Y. (2012) Spoilt and Lazy: The Impact of State Support on Bank Behavior in the International Loan Market. International Journal of Central Banking, 8, 121-173.

[2] Kim, M., Surroca, J. and Tribó, J.A. (2014) Impact of Ethical Behavior on Syndicated Loan Rates. Journal of Banking \& Finance, 38, 122-144. http://dx.doi.org/10.1016/j.jbankfin.2013.10.006

[3] Sharpe, S.A. (1990) Asymmetric Information, Bank Lending, and Implicit Contracts: A Stylized Model of Customer Relationships. Journal of Finance, 45, 1069-1087.

[4] Rajan, R.G. (1992) Insiders and Outsiders: The Choice between Informed and Arm's Length Debt. Journal of Finance, 47, 1367-1400. http://dx.doi.org/10.1111/j.1540-6261.1992.tb04662.x

[5] Boot, A.W.A., Greenbaum, S.I. and Thakor, A.V. (1993) Reputation and Discretion in Financial Contracting. American Economic Review, 83, 1165-1183.

[6] Diamond, D.W. and Rajan, R.G. (2000) A Theory of Bank Capital. Journal of Finance, 55, 2431-2465. http://dx.doi.org/10.1111/0022-1082.00296 
[7] Hubbard, R.G., Kuttner, K.N. and Palia, D.N. (2002) Are There Bank Effects in Borrowers’ Costs of Funds? Evidence from a Matched Sample of Borrowers and Banks. Journal of Business, 75, 559-581. http://dx.doi.org/10.1086/341635

[8] Steffen, S. and Wahrenburg, M. (2008) Syndicated Loans, Lending Relationship, and the Business Cycle. Working Paper, Goethe University Frankfurt.

[9] Santos, J.A.C. and Winton, A. (2008) Bank Loans, Bonds, and Informational Monopolies across the Business Cycle. Journal of Finance, 63, 1315-1359. http://dx.doi.org/10.1111/j.1540-6261.2008.01359.x

[10] Schenone, C. (2010) Lending Relationships and Information Rents: Do Banks Exploit Their Information Advantages? The Review of Financial Studies, 23, 1149-1199. http://dx.doi.org/10.1093/rfs/hhp080

[11] Hale, G. and Santos, J.A.C. (2009) Do Banks Price Their Informational Monopoly? Journal of Financial Economics, 93, 185-206. http://dx.doi.org/10.1016/j.jfineco.2008.08.003

[12] Santos, J.A.C. and Winton, A. (2009) Bank Capital, Borrower Power, and Loan Rates. European Financial Association Annual Conference 2009, Bergen Meeting Paper.

[13] Berger, A.N. and Udell, G.F. (1990) Collateral, Loan Quality and Bank risk. Journal of Monetary Economics, 25, 2142. http://dx.doi.org/10.1016/0304-3932(90)90042-3

[14] Bharath, S.T., Sunder, J. and Sunder, S.V. (2008) Accounting Quality and Debt Contracting. The Accounting Review, 83, 1-28. http://dx.doi.org/10.2308/accr.2008.83.1.1

[15] Gambacorta, L. and Mistrulli, P.E. (2004) Does Bank Capital Affect Lending Behavior? Journal of Financial Intermediation, 13, 436-457. http://dx.doi.org/10.1016/j.jfi.2004.06.001 